\title{
Diabetická noha
}

\section{Robert Bém, Michal Dubský, Vladimíra Fejfarová, Jitka Husáková, Veronika Wosková}

Centrum diabetologie, Institut klinické a experimentální medicíny, Praha

Diabetická noha (Syndrom diabetické nohy - SDN) je závažnou pozdní komplikací diabetu, která je spojena s vysokou morbiditou a mortalitou, přičemž často vede k amputaci dolní končetiny. Mezi hlavní rizikové faktory vzniku SDN patři neuropatie, infekce a ischemie. Zásadní pro snižení počtu amputací je prevence vzniku ulcerací. Efektivní dispenzarizace a aplikace preventivních opatření, jako jsou vhodné boty a péče o dolní končetiny, může snižit incidenci ulcerací v rámci SDN až o polovinu. Léčba defektů nohy u diabetiků je nákladná, spočívá zejména v odlehčení postižené končetiny, léčbě infekce a ischemie. Opomenuta nesmí být ani lokální léčba a uspokojivá kompenzace diabetu. Odborná péče o tyto pacienty by vzhledem k nutnosti multidisciplinárního prístupu měla být směřována do specializovaných podiatrických ambulancí.

Klíčová slova: diabetes mellitus, diabetická noha, amputace.

\section{Diabetic foot}

Diabetic foot (DF) is a serious late complication of diabetes associated with high morbidity and mortality, often leading to lower limb amputation. Risk factors for DF include neuropathy, infection, and ischemia. The prevention of ulceration is essential for reducing amputation rate. Effective follow-up of patients and application of preventive approaches such as using of appropriate shoes and foot care can reduce the incidence of ulcerations by up to $50 \%$. DF treatment is very expensive and includes offloading of the affected foot, treatment of infection and revascularization. Local treatment and satisfactory diabetes control are also very important. Professional care for these patients should be directed to specialized podiatric clinics due to the need for a multidisciplinary approach.

Key words: diabetes mellitus, diabetic foot, amputation.

\section{Úvod}

Diabetická noha - syndrom diabetické nohy (SDN) je definován jako infekce, ulcerace nebo destrukce hlubokých tkání nohy spojená s neurologickými abnormalitami a s různým stupněm ischemické choroby dolních končetin (noha - část končetiny distálně od kotníku) $(1,2)$. SDN je závažnou pozdní komplikací diabetu, která je spojena s vysokou morbiditou a mortalitou pacientů a se značnými finančními náklady na léčbu $(3,4)$. V průběhu života postihuje až $25 \%$ všech pacientů s diabetem, přičemž při současném výskytu diabetu, kdy je postiženo téměř 10 \% celé populace (5), se jedná o významné procento populace. Nejzávažnějším následkem SDN je vysoká amputace končetiny, tj. amputace v oblasti bérce či stehna. Amputaci u pacientů s diabetem v 85 \% předchází ulcerace nohy (Obr. 1.), přičemž 4 z 5 ulcerací jsou způsobeny vnějším traumatem, nejčastěji při nošení nevhodné obuvi (6). Nejefektivnější léčbou SDN je prevence jejího vzniku. Na prvním místě je třeba identifikovat rizi- kové pacienty formou pravidelného skríninku a dle stratifikace rizika následně aplikovat účinnou prevenci (7). Prognóza pacientů se SDN je velmi nepř́iznivá, často srovnatelná se závažnými onkologickými onemocněními (Obr. 2.) (8).

Obr. 1. Neuropatický defekt nohy u pacienta s diabetem

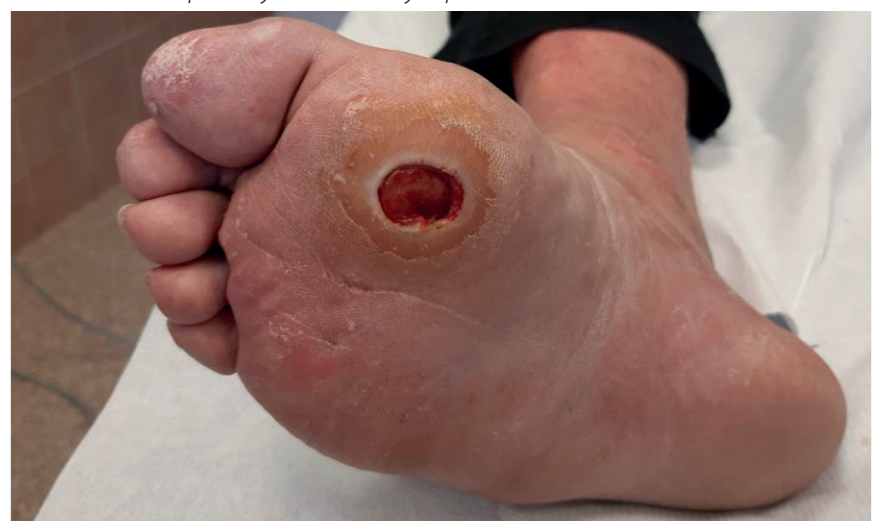




\section{Prevence syndromu diabetické nohy}

Na základě diagnostiky rizikových faktorů můžeme pacienty s diabetem zařadit do jedné z kategorií (0-3), od čehož se pak odvijí frekvence kontrol a samotná preventivní opatření. Stratifikace rizika a doporučená frekvence kontrol dolních končetin u pacientů s diabetem je uvedena v Tab. 1. Dle kategorie rizika SDN je pak třeba následně aplikovat preventivní opatření (7).

Mezi tato opatření patří zejména rádná edukace pacientů stran vhodné obuvi, ponožek a vložek, pravidelná sebekontrola nohou pacientem, hygiena nohou, pravidelné cvičení, pedikúra, uspokojivá kompenzace diabetu, léčba i drobných poranění nohy, a pokud již dojde ke vzniku ulcerace, tak včasná kontrola u odborníka na tuto problematiku (9).

Speciální pozornost se v poslední době věnuje riziku reulcerací (kategorie 3), které jsou zásadním rizikovým faktorem vysokých amputací. Dá se ríct, že pacient se zahojenou ulcerací není vyléčen stran SDN, ale pouze $\vee$ remisi (8).

\section{Rizikové faktory syndromu diabetické nohy a jejich diagnostika}

Vznik ulcerací v rámci SDN je nejčastěji podmíněn diabetickou neuropatií a ischemií; diabetická neuropatie byla prokázána u 85 90 \% diabetiků s ulcerací, ischemie byla prokázána asi u 45 \% pacientů (10). Pokud již dojde ke vzniku ulcerace, pak ta nezřídka bývá komplikována infekcí měkkých tkání nebo i skeletu (osteomyelitis). To už je jen malý krůček k nutnosti provedení amputačního výkonu. Tzv. schody k amputaci jsou znázorněny na Obr. 3.

Diabetická neuropatie působí negativně hned několika způsoby. Především dochází k poruše senzorických nervů, která vede k necitlivosti na bolestivé podněty, vnímání teploty a tlaku, což působí snadno vznik otlaků z obuvi. Pacienti nezřídka nosí boty, které jsou naprosto nevyhovující, ale pacientem jsou vnímány jako velmi pohodlné. Dále se jedná o smíšenou poruchu senzorických a motorických nervů, která vede při svalové dysbalanci mezi flexory a extenzory nohy ke vzniku deformit prstů i celé nohy. Významným

Tab. 1. Kategorizace rizika syndromu diabetické nohy

\begin{tabular}{|c|c|c|c|c|}
\hline Kategorie rizika & Charakteristika & Frekvence kotrol & Dispenzarizace & Obuv \\
\hline 0 = nízké riziko & $\begin{array}{c}\text { Zachována protektivní } \\
\text { citlivost }\end{array}$ & $1 \times$ ročně & Praktický lékař/diabetolog & Běžná \\
\hline 1 = střední riziko & $\begin{array}{c}\text { Senzorická neuropatie, bez } \\
\text { deformit, bez anamnézy } \\
\text { ulcerací a amputací }\end{array}$ & Každých 6 měsíců & Praktický lékař/diabetolog & Diabetická profylaktická \\
\hline 2 = vysoké riziko & $\begin{array}{c}\text { Senzorická neuropatie, } \\
\text { prítomnost deformit, bez } \\
\text { anamnézy ulcerací amputací }\end{array}$ & Každé 3 měsíce & Diabetolog/podiatr & $\begin{array}{c}\text { Diabetická profylaktická/ } \\
\text { individuální }\end{array}$ \\
\hline $3=$ velmi vysoké riziko & $\begin{array}{l}\text { Senzorická neuropatie, } \\
\text { př́tomnost ulcerací } \\
\text { a amputací v anamnéze, } \\
\text { renální insuficience }\end{array}$ & Každý 1-3 měsíc & Diabetolog/podiatr & Diabetická individuální \\
\hline
\end{tabular}

Obr. 2. Relativní Sletá mortalita u jednotlivých diagnóz syndromu diabetické nohy a vybranných onkologických onemocnění (8)

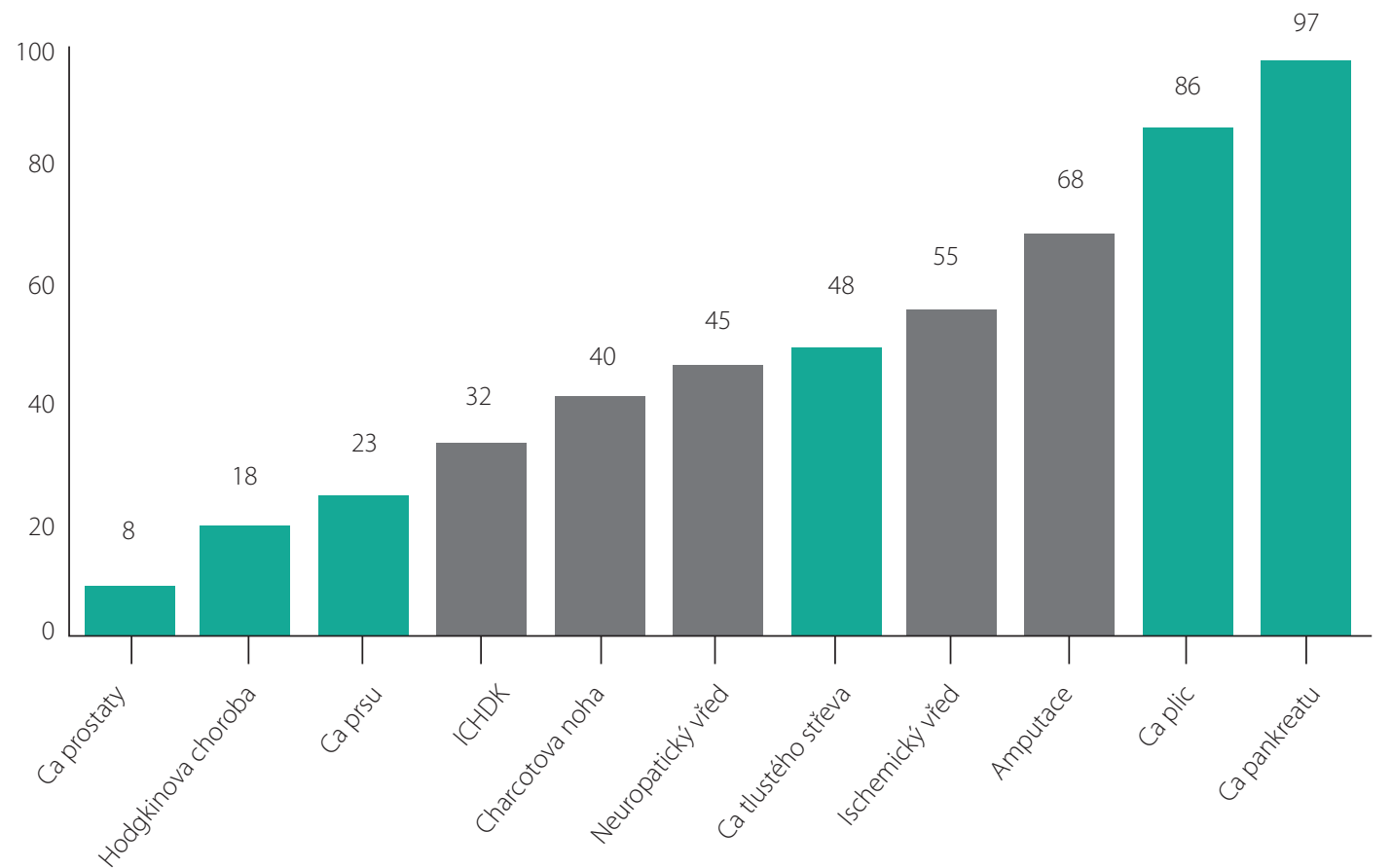


Obr. 3. Schody k amputaci

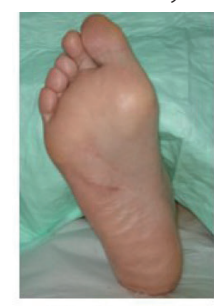

diabetes

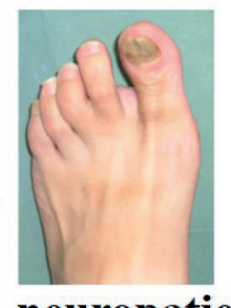

neuropatie

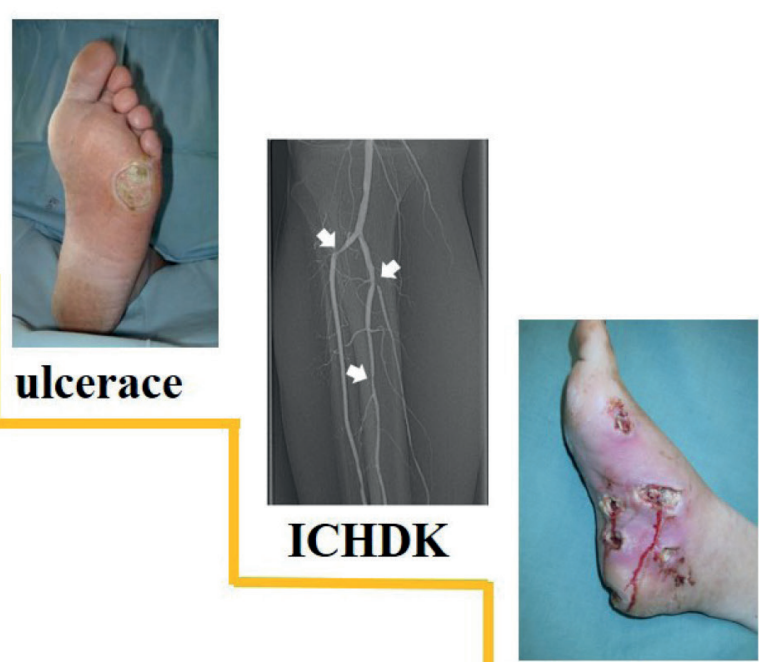

infekce

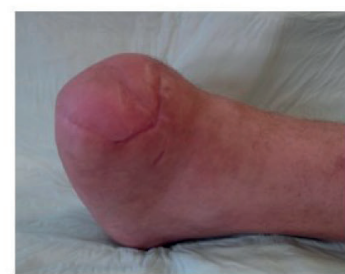

amputace patogenetickým faktorem je i autonomní neuropatie, která působí hyperemii především shuntovou cirkulací. Noha je proto zdánlivě dobře prokrvená, teplá až oteklá, avšak je snižený průtok nutritivními kožními a svalovými kapilárami (11). Diabetická neuropatie se vyšetřuje pomocí Semmes-Weinsteinových monofilament (hmotnost $10 \mathrm{~g}$ ), kde se hodnotí počet správně lokalizovaných dotyků monofilamenta na noze. Biothesiometr je pak používán ke stanovení vibrační citlivosti na noze. Výsledek je uveden ve voltech (V) a při hodnotě nad $25 \mathrm{~V}$ pak hovoříme o těžké periferní neuropatii. Další možností vyšetření periferní neuropatie je např. elektromyografie, skríninkovou metodou může být vyšetření pomocí tzv. Neuropadu.

Ischemická choroba dolních končetin (ICHDK) je závažnou pozdní komplikací diabetu, která nejenže může vést ke vzniku ulcerací nohy, ale je i velmi častou příčinou amputací. Diabetici s ICHDK mají poškozenou především nutritivní kapilární cirkulaci, kterou nelze ztotožňovat s diabetickou mikroangiopatií. Diabetická mikroangiopatie tak nepatří mezi přímé patogenetické faktory SDN. V počátečním stadiu ICHDK nemusí pacient pocitovat žádné príznaky. Později se může ischemie projevit typickým př́znakem - klaudikačními bolestmi, které jsou u pacientů s diabetem poměrně vzácné. Př́činou je diabetická neuropatie a odlišná lokalizace stenóz. Diabetes je spojen s aterosklerotickými změnami lokalizovanými na dolních končetinách především ve femoropopliteální a podkolenní oblasti; na rozdíl od jiných rizikových faktorů (kouření, hypertenze), které postihují oblast aorto-ileo-femorální (12). K diagnostice ICHDK se nejvíce se používá měěení periferních tepenných tlaků Dopplerem (index kotník/paže normální rozmezí je 0,8-1,2), transkutánní kyslík (TcpO2) na dorzu nohy a palcové tlaky. Standardem pro diagnostiku ICHDK, zejména před intervenčními cévními výkony (perkutánní transluminální angioplastikou - PTA, bypassem), u pacientů s diabetem je MR či CT angiografie.

Dalšími rizikovými faktory SDN jsou zvýšená kožní teplota, limitovaná pohyblivost kloubů, nevhodná obuv, deformity nohou, ulcerace v anamnéze, prèedchozí chirurgické zákroky (amputace) na dolních končetinách a další přidružené diabetické komorbidity (např. diabetická retinopatie a nefropatie). Schéma patogeneze SDN je uvedeno na Obr. 4.

\section{Léčba}

Léčba syndromu diabetické nohy je často obtižná a její úspěšnost velmi závisí na jejím včasném zahájení. Základem je multidisciplinární prístup (13).

Mezi nejdůležitější opatření při léčbě diabetických ulcerací je jejich maximální odlehčení. Bez odstranění tlaku na ulceraci je hojení velmi obtižné, prodlužuje se významně jeho délka a je vysoké riziko přechodu akutního defektu do chronického stadia (14). Terapie chronického defektu je pak mnohem náročnější, nezřídka pak vyžaduje delší a nákladnou terapii. Kodlehčení defektů využíváme celou řadu opatření a pomůcek. Mezi tyto pomůcky patří terapeutická obuv, kontaktní semirigidní fixace, ortézy, které se používají současně 
Obr. 4. Patogeneze syndromu diabetické nohy, úloha neuropatie, ischemie a infekce

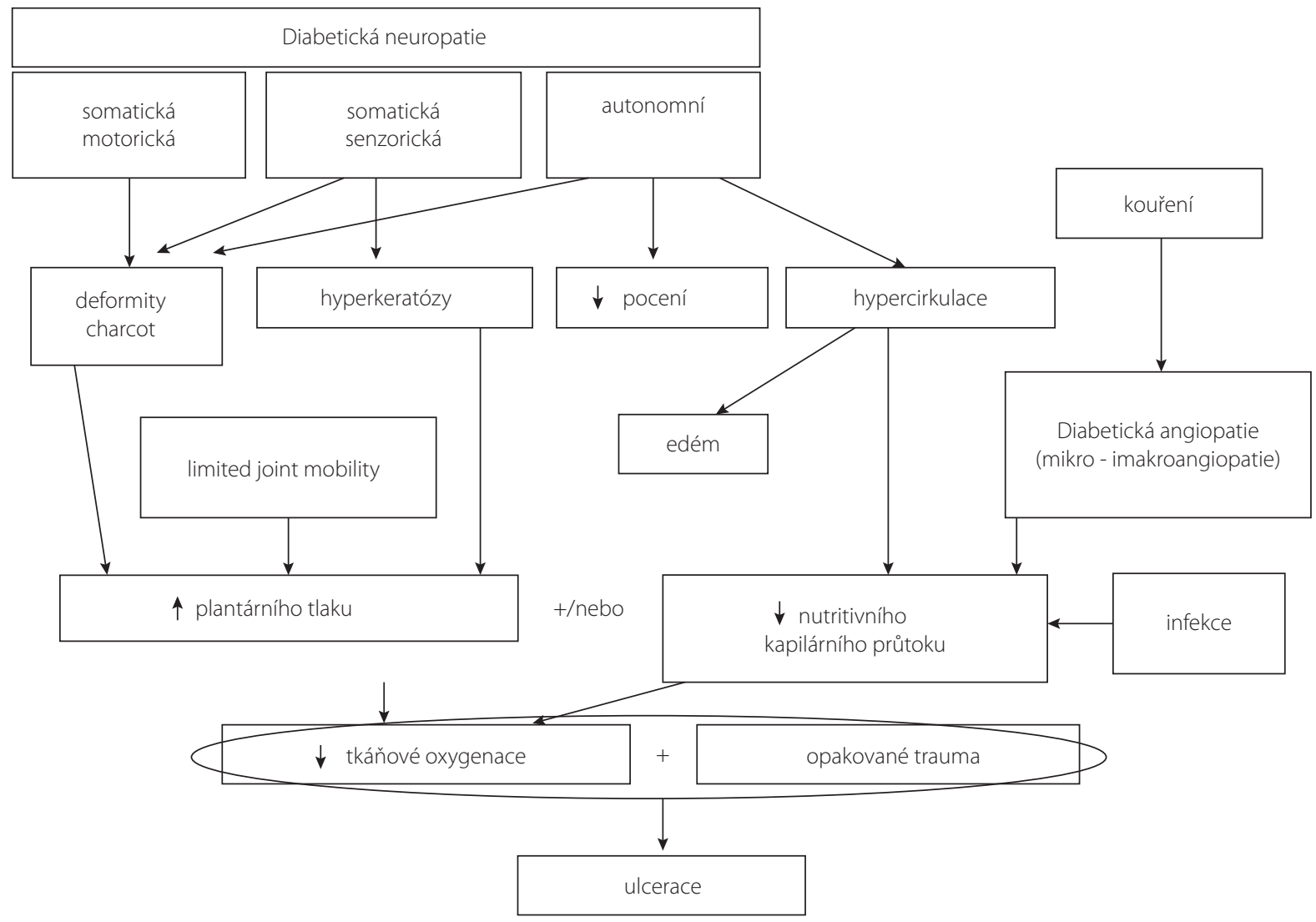

Obr. 5. Patogeneze Charcotovy neuropatické osteoartropatie

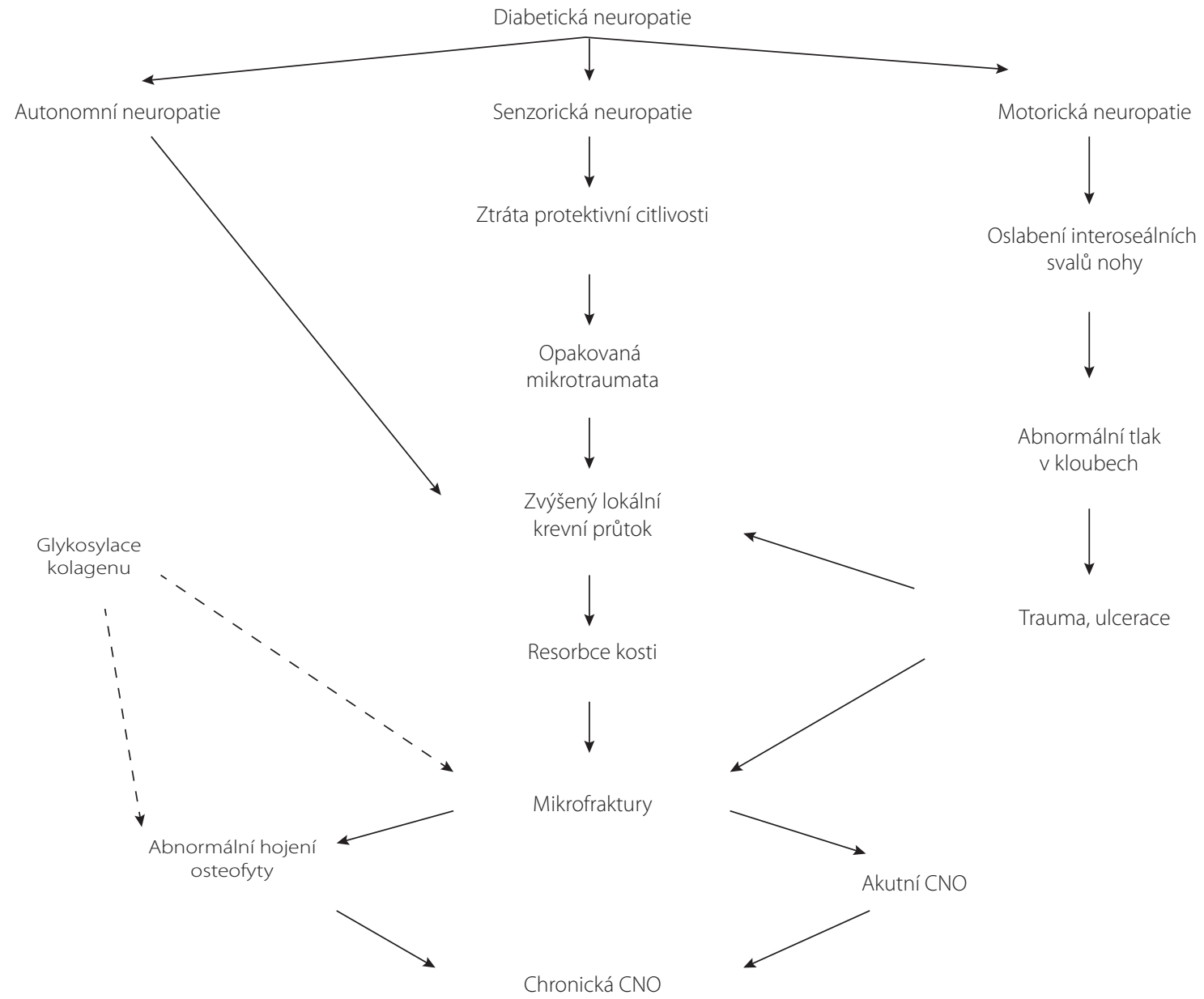


s podpažními berlemi. Zvláštní skupinu tvoří speciální odlehčovací vložky, individuálně vyrobené dle typu a lokalizace defektu, které pak můžeme vložit do terapeutické obuvi nebo ortézy. Při výskytu defektů na obou dolních končetinách je nutné odlehčení pomocí pojízdných vozíků. Ve zvláštních prípadech indikujeme klid na lůžku. Pacienti s diabetickými ulceracemi nohy nesmí chodit bez prostředků zajišťujících úplné odlehčení ulcerace. Užívání pomůcek k odlehčení je nutné i v domácím prostředí; studie ukazují, že pacienti v domácím prostředí nachodí přibližně stejnou vzdálenost jako při pohybu mimo domov, přičemž míra aktivity je př́mo úměrná riziku ulcerace (15).

U pacientů s prokázanou ischemickou chorobou dolních končetin a nehojící se ulcerací nohy je možností volby provedení angioplastiky (PTA) nebo periferního by-passu, v poslední době je i možnost léčby pomocí kmenových buněk (16). V prrípadě přítomnost známek infekce (otok, erytém, patologická sekrece z rány, zvýšená lokální teplota) je nutno zahájit adekvátní antibiotickou terapii nejprve empirickou, posléze dle klinického obrazu a výsledku kultivace z rány cílenou (17). Léčba osteomyelitis $(O M)$ u SDN je značně problematická a v současné době nejsou jasné doporučené postupy. Konzervativní léčba zahrnující zejména dlouhodobé podávání antibiotik je velmi zdlouhavá a nezřídka stejně končí amputačním výkonem. K této léčbě jsou indikováni pacienti s první atakou OM s dobrou citlivostí na ATB léčbu při uspokojivém prokrvení nohy a motivovaní spolupracující pacienti. Při selhání konzervativní terapie je indikováno chirurgické řešení - odstranění postižené kosti (resekcí nebo amputací) (18).

Další nezbytnou součástí terapie diabetických ulcerací je lokální léčba. V první fázi je nezbytný debridement - očištění rány a snesení hyperkeratóz. Podle typu rány pak přikládáme vhodné krytí. V současné době existuje celá raada typů krytí - inertní, antiseptické, hydrogely, algináty, hydrokoloidy, pěny (polyuretany), silikony, vlákna. Volba správného krytí pak může přispět k urychlení hojení ulcerace. Mezi moderní lokální léčbu patří léčba larvami, lokálním podtlakem, ozónem, chladnou plazmou či biologickými kryty (19-21).

Nesmí být opomenuta na léčba edémů, kompenzace diabetu a léčba dalších onemocnění ovlivňujících hojení.

\section{Charcotova neuropatická osteoartropatie}

Charcotova neuropatická osteoartropatie je chronické, progresivní onemocnění kostí a kloubů nohou vznikající na podkladě neuropatie (Obr. 5.) (22). Nejčastější príčinou periferní neuropatie je právě diabetes. $\checkmark$ akutním stadiu onemocnění je noha oteklá, zarudlá a se zvýšenou kožní teplotou, málokdy je končetina bolestivá (Obr. 6.). V tomto stadiu často není stanovena správná diagnóza, takže u řady pacientů dochází ke vzniku závažných deformit nohy. Základní diagnostickou metodou je čtyřfázová dynamická scintigrafie skeletu, popř. magnetická rezonance. Diagnostika pomocí RTG vyšetření je pozdní, často až ve stadiu komplikací (dislokace, fraktury) (23). Terapie se liší v jednotlivých stadiích podle aktivity onemocnění. Léčba aktivního stadia Charcotovy neuropatické osteoartropatie spočívá zejména v maximálním odlehčení postižené končetiny. $V$ některých prípadech je indikována antire-
Obr. 6. AktivníCharcotova noha (a), RTG nálezs typickým postižením skeletu (b)

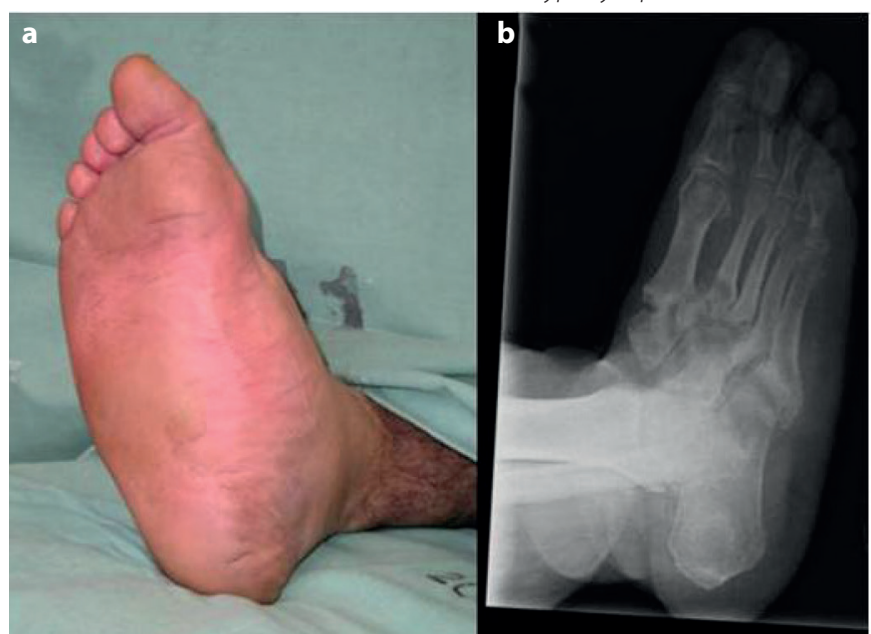

sorpční terapie, vždy za vyšetření parametrů kostního metabolismu (24). U pacientů s nestabilitou nohy je indikována stabilizace skeletu pomocí zevní či vnitřní fixace hřeby (25). Léčba pacientů s CNO, zejména $v$ akutním stadiu, musí být zahájena co nejdřive. Léčba je často zdlouhavá (nejčastěji trvá 3-12 měsíců) a klade velké nároky na spolupráci pacienta. U pacientů v chronickém stadiu onemocnění se musí dbát zejména na prevenci vzniku ulcerací, zvláště pak u pacientů s deformitami. Za předpokladu včasné diagnózy a vhodné terapie se může deformitám zcela předejít. U těchto pacientů je indikována profylaktická obuv, u pacientů s deformitami speciální ortopedická, která nemá za cíl korigovat deformitu, ale redukovat plantární tlaky na plosce. V ojedinělých prípadech může CNO postihnout kteroukoliv část skeletu - kolenní kloub, páteř, kyčelní kloub apod.

\section{Organizace péče o pacienty se SDN v rámci České republiky}

Komplexní péče o pacienty se SDN je zajištována především podiatrickými ambulancemi nejčastěji vedenými diabetologem. V současné doběje v České republice evidováno celkem 33 těchto ambulancí, přičemž seznam těchto ambulancí je uveden na webových stránkách České diabetologické společnosti (www.diab.cz). Vzhledem k vysokému počtu pacientů s diabetem v populaci je zřejmé, že k zajištění adekvátní péče je potřeba jedné podiatrické ambulance na 100 tisíc obyvatel, což např. v podmínkách ČR znamená potřebu 100 podiatrických ambulancí. Kritéria vzniku podiatrických ambulancí (personální zajištění, vybavení i návaznost na dalši odbornosti) jsou definovány výborem České diabetologické společnosti. Pravidelně probíhá hodnocení kvality a dostupnosti péče pomocí vnitřních a vnějších auditů, které probíhají každé dva roky.

\section{Závĕr}

Syndrom diabetické nohy je významný faktor podílející se na morbiditě a mortalitě pacientů s diabetem. Je proto nezbytné aktivně vyhledávat rizikové pacienty a prípadně včas zahájit adekvátní terapii, abychom předešli relativně vysokému počtu amputací u pacientů s diabetem, a tím i snížení kvality jejich života.

Literatura u autora a na www.casopisvnitrnilekarstvi.cz 